\title{
体外衝撃波結石破碎療法に打ける結石側要因の検討
}

\author{
国立病院医療センター泌尿器科 \\ 藤田 公生 佐山 孝* 松島 常 宗像 昭夫
}

\section{STONE BURDEN ON EXTRACORPOREAL SHOCK WAVE LITHOTRIPSY}

\author{
Kimio Fujita, Takashi Sayama, Hisashi Matsushima and Akio Munakata \\ Department of Urology, National Medical Center, Tokyo
}

Based on the 89 stones treated by ESWL therapy alone, the factors which influence the number of ESWL shots were analyzed. Stone volume was calculated by summing up the value "length $\times$ short axis" for each stone. The value correlated well with the number of shots needed to disintegtrate the stone $(\mathrm{p}<0.01)$. The stones below the pelvioureteral junction needed twice shots compared with stones in the pelvis and calyces (80.3: 40.2, $\mathrm{p}<0.005)$. Stones formed by a single component of cystine or calcium oxalate were hard to be disintegrated (53.2: 31.6, compared with other complex stones). The radiological figure could not predict the fragility.

Key words: ESWL, stone size, fragility

\begin{abstract}
要旨：体外衝撃波結石破研療法において, 治療に必要な衝撃波数に関与する因子を検討した，X 線写真 上における結石の長径と短径の積の総和は容易に得ることができ, 結石の総体積および必要衝撃波数を 示すよい指標になった $(\mathrm{p}<0.01)$. 腎孟尿管移行部以下の尿管結石は腎孟腎杯結石に比較して 2 倍の衝 撃波を必要とした $(80.3: 40.2 ， \mathrm{p}<0.005)$. ほぼ純粋な蓚酸カルシウム結石およびシスチン結石は他の 混合結石に比較して，必要な衝撃波数が多いといら傾向があった $(53.2: 31.6)$. X 線写真上の形から割 れやすさを判定することはできなかった。

キーワード：衝撃波療法, 結石サイズ, 硬度
\end{abstract}

\section{緒 言}

体外衝撃波による結石破砕療法（Extracorporeal Shock Wave Lithotripsy : ESWL) は Chaussy $ら^{11} に$ よって始められ，上部尿管結石に対して第一に考慮選 択されるべき治療法としての地位を短期間のうちに占 めるよらになった。本邦に批いても1984年から治療が 開始され，すでに多くの臨床経験が報告されている。 ここでは体外衝撃波結石破砕装置を用い，無麻酔下の 反復単独治療を行うことによって結石負荷 ${ }^{2}$ の問題に ついて検討することが出来たので報告する。

\section{対象と方法}

使用した装置はSonolith3000である，本機は水中放 電方式で, 放電圧が可変, 放電は心収縮に同期するよ らになっている．患者は原則として無麻酔で, 前処置 や前投薬は行わなかった。電圧を $12 \mathrm{kV}$ として治療し

* 現 東京大学泌尿器科
たが，後期には患者が疼痛に耐えられるよらなら 13.5 $\mathrm{kV}$ まで電圧をあげた。 入院患者については $2 \sim 3$ 日， 外来患者は $1 \sim 2$ 週に 1 回の間隔で反復治療をおこ なった．結石が大きくて，排出困難な結石の street

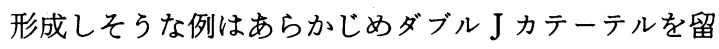
置した。尿管結石は，一部の例についてはカテーテル による腎孟内への押し上げを試みた。腸骨と重なる結 石が 2 例あったが，尿管カテーテルでやや上方に押し 上げて，他の場合と同様に背部から治療した。下部尿 管例の一部は座位で治療した。

結石の位置については, 細かく記載する横山の分類 を参考にして以下のようにした（図 1)。1：上腎杯 (ESWL 検討委員会によれば R2, 以下同様), 2 ：中腎 杯 (R2)，3：下腎杯 (R2)，4：腎孟 (R2)， 5 ：腎 孟尿管移行部(R3)，6：腎下極より上部の尿管(U1), 7 : 腸骨稜上縁までの尿管(U1)，8：腸骨と重なる部 位 (U2)， 9 : 仙腸関節より下部の尿管 (U3) の 9 分 
図 1 結石の位置と，それを破砕するのに必要であっ た衝撃波数。

腎盂腎杯内の結石はいずれも同様な衝撃波数を示 し，平均で $40.2 \pm 27.7 \mathrm{shots} / \mathrm{mm}^{2}$ であった。腎掹尿 管移行部以下の結石は $80.3 \pm 62.3 \mathrm{shots} / \mathrm{mm}^{2}$ と，約 2 倍の衝撃波を必要とした $(\mathrm{p}<0.005)$.

\begin{tabular}{l}
\multicolumn{1}{c}{ 位置 } \\
\hline 結石数
\end{tabular}

類である：ただし各腎杯に散在している結石は最大結 石の存在部位で分類し，鋳型結石のように大きな結石 が腎孟腎杯に分布している例は腎孟結石として分類し た。また，腎盂が直接に尿管に移行する形態の例には 腎孟尿管移行部という表現は用いずに腎孟結石とし， 図のように腎盎がいちど漏斗状にくびれて一見尿管様 の形態をとり，これが尿管に移行する部位に嵌頓して いる結石を腎孟尿管移行部の結石とした。

結石の大きさについては，X 線写真上で各結石陰影 の長径と，それと直交する短径を測定した。この際， 回転棈円体を想定してそれに近似するといら考え方 で，小さい突起は無視して平均的な外形をとった。各 結石についての積の和を結石全体の大きさの指標とし た。

結石の形状を陰影の輪郭から，1．雪結晶状，2，不 整形，3. 円形の 3 段階に分類し，また陰影の密度分布 から，1. 粗，2．層状ないし不均一，3. 均一の 3 段階 に分類した。

排出された結石は可能な限り採取して，赤外線分析 によって成分を同定した。

残石については, $4 \mathrm{~mm}$ 以上の排出困難な結石のある ときは破砕治療を反復することにした。

\section{結 果}

対象となった症例は79例89結石で男49例，女30例， 年齢は平均 $( \pm \mathrm{SD})$ が $47.6 \pm 14.2$ 歳 (14 79歳)であっ た.
図2 結石影と結石の体積との関係

いくつかのモデル系において，長径が投影された場 合の曲線を描き, 実際の結石の測定値をあてはめた。

1. 球体, 2 . 長径と短径の比が $2 ： 3$ の長径を回転 軸とした回転棈円体，3. 同じく長径と短径の比が 1：2 の回転棈円体，4，2：3の回転棈円体が $1 / 2$ の大きさの相似体を伴った場合， 5 . 同じく2/3の大 きさの相似体を伴った場合, 6 . 同じ大きさの回転棈 円体が 2 個ある場合

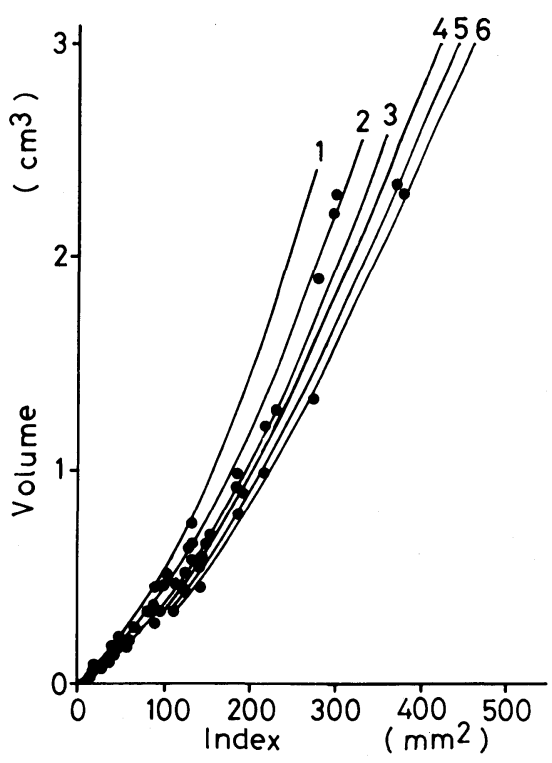

図 2 に結石影と結石の体積の関係を検討した。いく つかのモデル系において陰影に長径が投影された場合 の曲線を描き，実際の結石の測定值をあてはめてみた。 指標は二次元であるので，相似型の立体ならば大きく なるほど指標の増加が体積の増加に追いつかないこと になるが，例えば完全な球体が腎孟腎杯の中で大きく 育つのは不可能であり，次等に複雑な形態をとり，小 結石を伴って図の右方の線に移動していくので，この 指標と総体積との間には比較的比例関係が保たれてい た.

つぎに最大結石の大きさを指標としたときと, 総和 を指標としたときに，どちらが治療に必要な衝撃波数 を示すよりよい指標になるかを検討した（表 1 ). 次項 に述べるように尿管結石では平均して腎（腎監杯） 結石の 2 倍の衝撃波を必要とすることがわかったので 両者を分ける必要があり，種々な大きさの結石が存在 する腎結石を検討の対象とした。衝撃波数を結石の大 きさで除した值であると必要衝撃波数と最大結石との 関係を検討すると相関係数 $0.344203 て ゙ 95 \%$ の信頼度で 
表 1 腎結石の大きさの指標と破砕に必要な 衝撃波数の相関度

\begin{tabular}{c|c|c|c}
\hline & 例数 & 相関係数 & 信頼度 \\
\hline 最大結石 & 44 & 0.344203 & $95 \%$ \\
総和指数 & 44 & 0.484244 & $99 \%$ \\
単一結石 & 31 & 0.839747 & $99 \%$ \\
\hline
\end{tabular}

*: 対象結石が一個の例のみについて相関をみた。 総和が最大結石の大きさと一致する例であり， 状況が単純で, 相関係数は最も高くなっている。

有意なのに対し, 結石総和との関係では相関係数 0.484244 で信頼度 $99 \%$ で有意と，ょり密接な関係を示 した. 参考に, 複数の結石が散在している症例に比べ て単純な系である, 単一結石症例のみに限って相関度 をみたところ, 結石の大きさと衝撃波数との間には相 関係数0.839747で，より密接な関係が得られた。

図 1 には結石の位置と, その結石を破砕するのに必 要であった衝撃波数を示してある。カテーテルによる 押し上げに成功してから治療した例は腎孟結石と分類 して必要衝撃波数を計算した。この衝撃波数は腎衁腎 杯結石はいずれもほぼ同じであり，腎孟尿管移行部以 下で高い值を示した。ただし膀胱近接部の尿管結石に 対する必要衝撃波は少なかった。この結果から腎孟腎 杯結石は細分類する必要はなく，一括して腎結石とし てよいこと，腎孟尿管移行部の結石は尿管結石として 考えるべきことが判明した. U1については，腎下極の 高さより上か下かによる差はなかった。腎盘尿管移行 部以下の結石を尿管結石とすると，治療に必要であっ た衝撃波数は $80.3 \pm 62.3 \mathrm{shots} / \mathrm{mm}^{2}$ で腎盂腎杯内の結 石の $40.2 \pm 27.7 \mathrm{shots} / \mathrm{mm}^{2}$ の 2 倍であり, 明らかに有 意な差を示した $(\mathrm{p}<0.005)$.

因 3 には結石の大きさと，その結石の破砕に必要で あった衝撃波数を一部の例について示した，尿管結石 にあまり大きなものはないこと，乙かも小さい結石に もかかわらず多くの衝撃波が必要であったこと，腎結 石が非常に大きいときはその砕片化が効率よく行わ れ，小さくなると陰影の減少効率が悪くなることが示 されている.

陰影からみた結石の性状から必要衝撃波を予測する 試みは，有意な相関を見いだすことができなかった。 表 2 に腎結石と尿管結石に分けたらえで，一見もっと も破砕が容易と思われた結晶状で粗な結石と，破砕が 困難と思われた円形で均一な結石を比較した結果を示 した。形態による差は全くみられず，尿管結石の衝撃
図 3 結石の大きさとその結石の破碎に必要であった 衝撃波数。

尿管結石にあまり大きなものはないこと，しかも結 石の大きさの割に多くの衝撃波が必要であったこ と，また非常に大きい腎結石はその砕片化が効率よ く行われ，小さくなると陰影の减少効果が悪くなる ことが示されている.

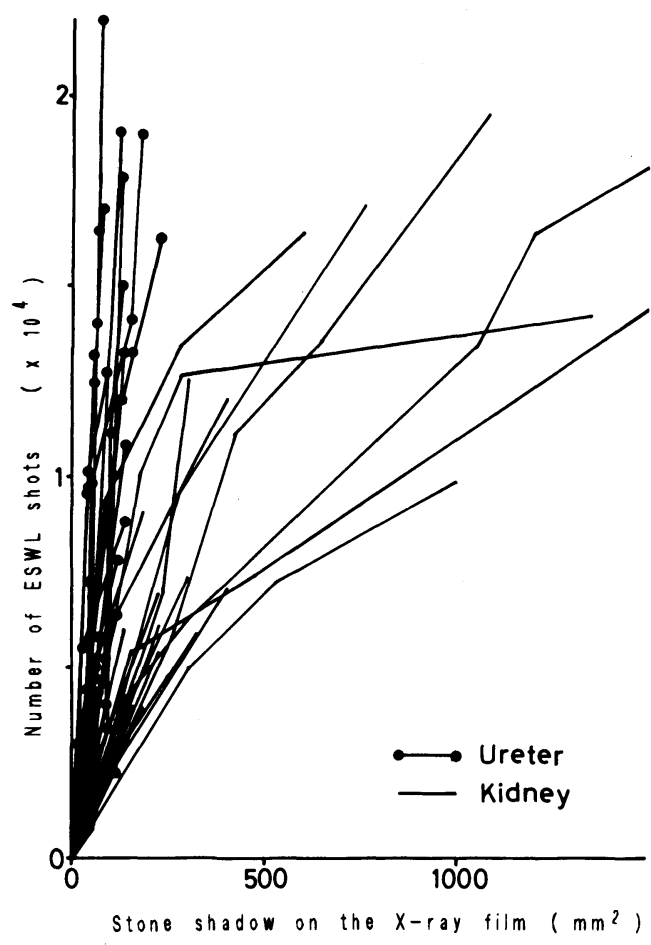

表 2 結石の性状と衝撃波数 (shots $/ \mathrm{mm}^{2}$ )

\begin{tabular}{c|c|c}
\hline & 雪結晶状で粗 & 円形で均一 \\
\hline 腎結 石 & $38.1 \pm 19.3$ & $38.9 \pm 31.8$ \\
& $(\mathrm{n}=8)$ & $(\mathrm{n}=19)$ \\
尿管結石 & $86.2 \pm 67.7$ & $85.4 \pm 53.7$ \\
& $(\mathrm{n}=14)$ & $(\mathrm{n}=7)$ \\
\hline
\end{tabular}

波数が腎結石の 2 倍であるといら関係が細分類された 群間においても保たれていた。

結石成分との関係では，ほぼ純粋なシスチン結石お よび蓚酸カルシウム結石は破碎しにくく, 混合結石, とくに炭酸カルシウムをふくむ種々な成分を複雑にふ くむ結石は破砕されやすいといら関係が示された（表 3 ). 純粋なシスチンないし蓚酸カルシウム結石（n= 9）と混合結石（ $\mathrm{n}=17 ）$ に大別してみると衝撃波数は $53.2 \pm 29.7$ 対 $31.6 \pm 25.3$ であった $(0.05<p<0.1)$. 
表 3 結石成分と衝撃波数

\begin{tabular}{l|r|r|c}
\hline \multirow{2}{*}{ 成 分 } & \multirow{2}{*}{ 全例数 } & \multicolumn{2}{|c}{ 腎 結 石 } \\
\cline { 3 - 4 } & & 例数 & 衝撃波数 \\
\hline & & & $\left(\right.$ shots $\left./ \mathrm{mm}^{2}\right)$ \\
シスチン & 3 & 3 & $59.9 \pm 36.5$ \\
葆酸 $\mathrm{Ca}(>98 \%)$ & 11 & 6 & $49.8 \pm 25.0$ \\
苳酸 $\mathrm{Ca}+$ 燐酸 $\mathrm{Ca}$ & 28 & 13 & $29.5 \pm 9.9$ \\
苳酸 $\mathrm{Ca}+$ 尿酸 & 1 & 1 & \\
尿酸 & 1 & 0 & \\
燐酸 $\mathrm{Ca}, \mathrm{NH} 4+$ 炭酸 $\mathrm{Ca}$ & 1 & & \\
燐酸 $\mathrm{Ca}+$ 炭酸 $\mathrm{Ca}+$ 蓚酸 $\mathrm{Ca}$ & 1 & 3 & $10.3 \pm 0.6$ \\
燐酸 $\mathrm{Mg}, \mathrm{NH} 4, \mathrm{Ca}+$ 炭酸 $\mathrm{Ca}$ & 1 & & \\
\hline
\end{tabular}

\section{考察}

体外衝撃波治療に拈いて, 結石の破砕しやすさにつ いては治療の成功率という観点からの検討があるが, 必要な衝撃波数からの分析はほとんどない。これは, 初期においては反復治療は現実の問題として考兄られ なかったことと, 圧電素子型の機種に打いては衝撃波 数などといら簡単な数值で表現することが出来ないた めであろう。

結石の大きさをどら表現するかといら課題について は種々な方法がとられている，わが国の ESWL 検討 委員会では簡易な方法として最大結石の長径のみを記 載することにしている. Griffith らは最大結石の長径 とともに, 各結石の長径の和を求め, surgical burden として表現している2)，われわれはX $\mathrm{X}$ 線写真上の陰影 面積を長径と短径の積の和として表現すると, 実際の 結石の体積と良好な比例関係があることを知り（図 2 ), 指標として用いている. 長径のみを指標とするよ りも短径との積をとったほうが実際の体積に近づき, また最大結石のみをみるよりも総和をとったほらがよ りよい指標になることは, 結石の形の多様性, 同大の 結石が 2 個あったときのことを考えると当然と思われ る.この指標が結石の大きさのみでなく治療に必要な 衝撃波数とも密接な関係にあることが今回の検討で示 された. 細かい突起は無視し、コンピュータグラフィッ クで種々な大きさの球体の集合で複雑な立体をつくり あげていくのに似た感覚で採寸すると，より望ましい 数值が得られると思われる。 また，細かい結石はいち いち計算しても総和に対する寄与率は小さくなるので 省略してもよい。この数值は臨床的に容易に得られ， 有用な指標と考えられる。

尿管結石が破碎されにくいということはいずれの施 設によっても観察されている. Mueller らはペンロー
スドレインにいれた石に衝撃波を与え, 結石の周囲か ら破砕が始まっているにもかかわらず破片はそのまま 留まり，以後の衝撃波による破砕を妨げていると述べ ている ${ }^{3)}$. 今回の検討では，この破砕されにくさを 2 倍 といら数值で表現されている，仙腸関節を通り過ぎた 下部尿管については，比較的少ない衝撃波で治療でき ることをPettersson らも観察している4)。これは下部 尿管に拈いては，ある程度の大きさに破碎すれば容易 に排出されるためであろう。

大きさと位置に次ぐ第 3 の因子として, 衝撃波に よって割れにくい性質の結石という問題があるが5)，X 線写真上の陰影の性状から割れやすい結石かどうかを 判定することはできなかった，今回のよらな分類が必 ずしも結石成分を反映しなかったことが大きな理由で

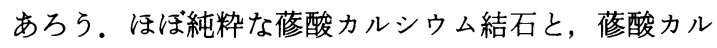
シゥムと燐酸カルシゥムの混合結石は種々な形態をと り全分類に分布した。純粋な尿酸結石は尿管に 1 例 あったのみで，その例が特に割れやすいといら結果は 得られなかった. Struvite と思われる成分の結石は丸 く均一な結石として分類されていたが, むしろ衝撃波 数は少なかった。 シスチン結石がもっとも破砕しにく い結石であることは確認された。苳酸カルシウム, と くに monohydrate が破砕しやすいという結論は, 以 上の結果から出なかった。混合結石は破碎しやすくて 純粋な蓚酸カルシウム結石は割れにくいといらのは, 均一な結晶を形成できるからであると考学るとそれな りに理解できる結果である。

以上を要約すると, 体外衝撃波単独療法で, 排出で きるところまで反復治療することによって結石の破砕 に必要な衝撃波数を検討することができた。結石の大 ささについては，X 線写真上で各結石の長径と短径の 積を加算していくことでよい指標を得られた。結石の 位置については, 腎孟腎杯結石は細分類する必要はな かった。腎盂尿管移行部以下の結石は同じ大きさの腎 孟腎杯結石の 2 倍の衝撃波を必要とした。腎下極以上 と以下を区別する必要もなく, わが国の ESWL 検討 委員会の分類は妥当なものであることが確認された。 下部尿管結石は比較的容易に排出された。結石の形態 から必要衝撃波数に差を求める試みは失敗に終わっ た. 結石成分との関係ではシスチン結石がもっとも破 砕しにくく，混合結石は破碎が容易であった。

\section{文献}

1) Chaussy, C., Brandel, W. and Schmiedt, E. : Extracorporeally induced destruction of kidney 
stones by shock waves. Lancet, ii, $1265-1268$, 1980.

2) Griffith, D.P. and Valiquette, L.: PICA/burden: A staging system for upper tract urinary stones. J. Urol., 138, 253-257, 1987.

3) Mueller, S.C., Wilbert, D., Thrueroff, J.W. and Alken, P.: Extracorporeal shock wave lithotripsy of ureteral stones: Clinical experience and experimental findings. J. Urol., 135,
831-834, 1986.

4) Pettersson, B. and Tiselius, H.-G.: Extracorporeal shock wave lithotripsy of proximal and distal ureteral stones. Eur. Urol., 14, 184-188, 1988.

5) Dretler, S.: Stone fragility-A new therapeutic distinction. J. Urol., 139, 1124-1127, 1988.

(1990年 2 月 5 日受理) 